\title{
The Effects of Maternal Parenting Behaviors on Toddlers' Externalizing Problem Behaviors: The Mediating Effect of Compliance
}

\author{
Bokyung Park ${ }^{1}$, Minjoo Kim², Nana Shin ${ }^{3}$, Kibong Yun ${ }^{4}$, Jee Un Noh \\ Assistant Professor, Department of Education for Child Care, Kyungmin University, Uijeongbu, Korea ${ }^{1}$ \\ Research Professor, Child \& Family Research Institute, Ewha Womans University, Seoul, Korea ${ }^{2}$ \\ Assistant Professor, Department of Child Development \& Intervention, Ewha Womans University, Seoul, Korea ${ }^{3}$ \\ Postdoctoral Researcher, Child \& Family Research Institute, Ewha Womans University, Seoul, Korea ${ }^{4}$ \\ Ph. D. Student, Department of Child Development \& Intervention, Ewha Womans University, Seoul, Korea ${ }^{5}$

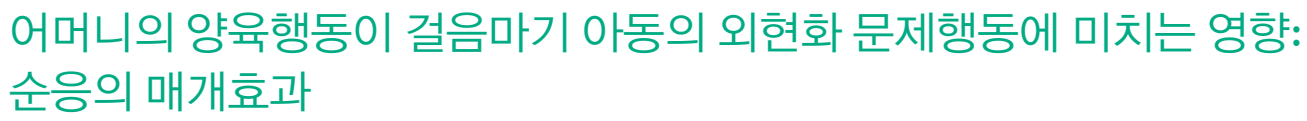

Objectives: This study examined the mediating effect of toddlers' compliance in the relationship between maternal parenting behaviors and externalizing problem behaviors.

Methods: A total of 432 mothers of 18- to 36-month-old toddlers responded to questionnaires on three research variables. Data were analyzed using SEM.

Results: First, while positive maternal parenting behaviors did not have a direct effect on toddlers' externalizing problem behaviors, negative maternal parenting behaviors had a direct effect on toddlers' externalizing problem behaviors. That is, toddlers whose mothers exhibited more negative parenting behaviors showed more externalizing problem behaviors. Second, positive and negative maternal parenting behaviors had indirect effects on toddlers' externalizing problem behaviors through compliance. In other words, when mothers displayed fewer positive parenting behaviors or more negative parenting behaviors, their toddlers tended to be less compliant, which led to more externalizing problem behaviors.

Conclusions: These findings contribute to a better understanding of the mechanism by which maternal parenting behaviors influence toddlers' externalizing problem behaviors. In addition, this study confirmed that negative maternal parenting behaviors play an important role in the development of noncompliance and externalizing problem behaviors in toddlers.

Keywords: maternal parenting behaviors, compliance, externalizing problem behaviors, toddler

Corresponding Author: Minjoo Kim, Research Professor, Child \& Family Research Institute, Ewha Womans University, 52, Ewhayeodae-gil, Seodaemun-gu, Seoul, Korea

E-mail:mj24@ewha.ac.kr
(C)The Korean Association of Child Studies

This is an Open Access article distributed under the terms of the Creative Commons Attribution Non-Commercial License (http:// creativecommons.org/licenses/by-nc/4.0) which permits unrestricted noncommercial use, distribution, and reproduction in any medium, provided the original work is properly cited. 


\section{Introduction}

걸음마기는 언어 발달이 급격히 이루어질 뿐만 아니라 자아의 발달과 함께 자기주장이 강해지고 부정성(negativity)이 증가 하며 자율성이 나타나는 시기이다(S.-Y. Park, 2006). 이러한 발 달적 특성으로 인해 일반적으로 주양육자가 되는 어머니는 걸 음마기 아동을 양육하며 이전 시기와는 다른 어려움에 직면하 게 된다. 또한, 이 시기 아동이 어머니의 요구나 기대에 따르거 나 따르지 않는 행동인 순응 또는 불순응은 발달적으로 중요 한 이슈가 된다. 순응은 외적 통제에서 내적 통제로 나아가는 중간 단계일 수 있으며(Kochanska \& Aksan, 1995), 우리가 속 한 사회의 기준과 기대에 맞춰 자신의 행동을 조절하고 통제 하는 것을 배우는 중요한 사회화 과정 중 하나가 될 수도 있다 (Chen et al., 2003). 뿐만 아니라 이는 이후 양심 발달에 기초가 되는 것으로 알려져 있다(Kochanska, 1991). 이러한 순응은 양 육자의 요구에 반응하는 형태로 9-12개월경부터 나타나기 시 작하며 생애 초기에 커다란 성장을 보인다(Kopp, 1982). 종단 연구에 의하면 걸음마기 아동의 순응 또는 불순응은 유아기까 지 상당히 안정적이며(Kuczynski \& Kochanska, 1990; Laurin \& Joussemet, 2017; Smith, Calkins, Keane, Anastopoulos, \& Shelton, 2004), 아동기부터 청소년기까지도 비교적 안정적인 경향이 있음이 보고된다(Kalb \& Loeber, 2003).

국내에서 아동의 순응 또는 불순응에 대해 다룬 선행 연구 들을 고찰해보면, 아직 그 수가 많지 않은 실정으로, 학령 전 의 영유아기 아동을 대상으로 연구되었다. 구체적으로는 만 1-2세 영아기 아동(Baek \& Cho, 2010), 18-36개월 걸음마기 아 동(S.-Y. Park, Rubin, Chung, Yoon, \& Doh, 2007; S.-Y. Park \& Shin, 2007), 만 3-6세 유아기 아동(Kim \& Yi, 2004; H. S. Park \& Han, 2001; Shin et al., 2014; Shin, Park, Kim, \& Doh, 2015; H. Song, 2018; H. Song \& Choi, 2007; Yong \& Park, 2011)을 대 상으로 연구가 진행되었는데, 유아기 아동을 대상으로 한 연 구들이 상대적으로 많이 이루어졌고 걸음마기 아동을 대상으 로 한 연구들은 소수에 불과하다. 앞서 언급한 것처럼, 양육자 의 요구나 지시를 받아들이고 따르는 행동인 순응은 걸음마기 의 발달적 특성과 맞물려 특히 걸음마기 시기에 강조되는 개 념 중 하나이므로, 이 시기 아동의 순응에 대한 국내 연구자들 의 보다 많은 학문적 관심이 요구된다.

국내외 연구자들은 아동의 순응 행동에서의 개인차를 설 명하기 위해 부모의 사회화에 주목하였으며(e.g., Chen et al., 2003; Laurin \& Joussemet, 2017), 특히 주양육자인 어머니에 초 점을 두어 주로 연구를 수행하였다. 어머니의 양육가치나 양
육신념, 인성 등에 대해 다룬 선행 연구들도 보고되나(Kim \& Yi, 2004; Lehman, Steier, Guidash, \& Wanna, 2002), 대체로 어 머니와 아동 간의 긍정적 정서(Kochanska \& Aksan, 1995), 어머 니의 정서적 가용성(Lehman et al., 2002), 통제 전략(Kochanska \& Aksan, 1995; Shin et al., 2014), 지시 유형(H. Song \& Choi, 2007), 양육행동(Chen et al., 2003; H. S. Park \& Han, 2001; S.-Y. Park \& Shin, 2007; Spinrad et al., 2012; Yong \& Park, 2011), 애착 안정성(Kok et al., 2013) 등과 같은 어머니와 아동 간의 상호작 용 측면에 많은 관심을 가져왔다. Kochanska와 Aksan (1995)은 아동이 어머니의 의견을 수용하고 순응하는 데 어머니와 아동 상호 간의 긍정적 정서가 중요함을 강조하였는데, 어머니가 긍 정적 양육행동을 보이는 경우 아동은 어머니와 긍정적 정서를 주고받으며 기꺼이 어머니의 요구나 기대를 받아들이고자 하 는 한편, 어머니가 부정적 양육행동을 보이는 경우 이와 반대 로 아동에게 부정적 정서가 유발되어 아동은 어머니의 기준이 나 기대를 무시하거나 거부 또는 반항할 수 있을 것이다.

실제로, 어머니의 양육행동과 걸음마기 아동의 순응에 대 해 살펴본 국내외 선행 연구들에 의하면, 어머니의 민주적 양 육태도나 온정, 민감성, 구조화(structuring), 한계 설정, 논리적 설명(induction/reasoning), 긍정적 지도 등은 걸음마기 아동의 높은 순응과 관련되며(Calkins, Smith, Gill, \& Johnson, 1998; Chen et al., 2003; Feldman \& Klein, 2003; Feng, Hooper, \& Jia, 2017; Lehman et al., 2002; S.-Y. Park \& Shin, 2007; Spinrad et al., 2012), 어머니의 독재적 양육태도나 처벌 지향(punishment orientation), 부정적 통제 등은 걸음마기 아동의 낮은 순응 또 는 불순응과 관련되었다(Calkins et al., 1998; Chen et al., 2003; Laurin \& Joussemet, 2017; S.-Y. Park \& Shin, 2007). 이와 유사 하게 유아기 아동을 대상으로 한 연구들에서도 온정, 한계 설 정, 합리적 지도 등과 같은 어머니의 긍정적 양육행동은 유아 의 순응과 정적 상관이(H. S. Park \& Han, 2001; Yong \& Park, 2011), 강압, 통제 등과 같은 어머니의 부정적 양육행동은 유 아의 순응과는 부적 상관이, 불순응과는 정적 상관이 나타났 다(Smith et al., 2004; Yong \& Park, 2011). 뿐만 아니라 종단 연 구에서도 24 개월 때 어머니의 자율성 지지는 40 개월 때 유아 의 순응과 정적 상관을, 어머니의 통제는 40 개월 때 유아의 순 응과 부적 상관을 보였으며(Laurin \& Joussemet, 2017), 30-33 개월 때 어머니의 반응성은 40 개월 때 유아의 순응과 정적 상 관을 보였다(Kochanska \& Kim, 2013). 몇몇 선행 연구들은 어 머니와 자녀 간 상호작용을 관찰함으로써 어머니의 통제 전 략이나 지시 유형에 대해 살펴보았는데, 어머니가 논리적 설 명이나 제안과 같이 통제의 정도가 심하지 않은 온화한 통제 
를 보일 때 26-41개월 아동은 순응 행동을 더 많이 나타낸 반 면, 어머니가 위협이나 신체적 처벌과 같이 부정적 통제를 보 일 때 26-41개월 아동은 불순응 행동을 더 많이 나타내었다 (Kochanska \& Aksan, 1995). 이후 후속 연구들에서도 이와 유 사하게 걸음마기 또는 유아기 아동은 장난감 정리 상황에서 어머니가 칭찬이나 온화한 통제를 많이 보일수록 순응을 더 많이 나타내고(Feldman \& Klein, 2003; Shin et al., 2014), 어머 니가 지시나 명령, 요구를 많이 할수록 불순응을 더 많이 나타 내었다(Shin et al., 2014; H. Song \& Choi, 2007). 이와 같은 국 내외 선행 연구들을 근거로, 어머니의 긍정적 양육행동은 자 녀의 높은 순응성과, 어머니의 부정적 양육행동은 자녀의 낮 은 순응성과 관련있을 것으로 예측해볼 수 있다. 국외의 한 연 구에서는 특히 어머니의 양육행동이 걸음마기 아동의 어머니 에 대한 순응뿐만 아니라 보육교사와 같은 다른 양육자에 대 한 순응도 예측함을 밝혀(Feldman \& Klein, 2003), 어머니의 양 육행동이 어머니에 대한 순응을 높이고 이러한 어머니에 대한 순응이 다른 사람에 대한 순응으로 일반화될 수 있음을 확인 하여 아동의 순응성 발달에 있어 어머니 역할의 중요성을 강 조하였다. 국내의 경우 걸음마기 아동을 대상으로 어머니의 양육행동과 아동의 순응 간의 관계를 다룬 선행 연구들이 부 족하므로, 걸음마기 아동을 대상으로 이에 대해 살펴보고자 하였다.

양육자의 요구나 지시에 대한 아동의 반응인 순응은 자기 조절이 나타나는 초기 형태이며(Kopp, 1982), 사회적 규칙을 내면화하는 데 기초가 된다(Kochanska \& Aksan, 1995). 따라서 아동의 순응은 사회적 적응에 영향을 미칠 수 있는데, 예를 들 어 아동의 높은 순응성은 다른 사람과 상호작용할 때 사회적 으로 바람직한 행동을 촉진할 수 있는 반면, 낮은 순응성은 통 제의 부족을 의미하여 문제행동으로 연결될 수 있다. 이에 몇 몇 연구자들은 아동의 순응 또는 불순응과 외현화 문제행동 간의 관계에 관심을 가졌으며, 국외의 연구들에서는 24 개월 때 아동의 불순응과 36 개월 때 외현화 문제행동 간의 정적 관 련성을(Keenan, Shaw, Delliquadri, Giovannelli, \& Walsh, 1998), 3 세 아동의 불순응과 외현화 문제행동 간의 정적 관련성을 (Combs-Ronto, Olson, Lunkenheimer, \& Sameroff, 2009), 40개 월 아동의 순응과 외현화 문제행동 간의 부적 관련성을 발견 하였다(Kochanska \& Kim, 2013). 뿐만 아니라 종단 연구들에 서는 걸음마기 아동의 순응이 유아기 아동의 외현화 문제행동 이나 공격성을 예측함을 밝혔는데, 걸음마기 아동의 순응은 5 세 때 외현화 문제행동과 부적 상관을 보인 반면, 반항과 같은 걸음마기 아동의 불순응은 5 세 때 외현화 문제행동과 정적 상
관을 보였다(Kuczynski \& Kochanska, 1990). 또한, 2세 때 어머 니와의 상호작용에서 아동이 보인 불순응은 4 세 때 또래와의 상호작용에서의 언어적 및 신체적 공격성으로 연결되었으며 (Chen, Chen, Wang, \& Liu, 2002), 3세 때 실험실 상황에서 아 동이 나타낸 불순응은 6세 때 어머니와 교사 보고로 측정한 외 현화 문제행동과 관련되었다(Combs-Ronto et al., 2009). 국내 의 경우 아동의 순응에 대한 선행 연구들이 순응의 결과보다 는 그 원인을 살펴보는 것에 초점을 두고 있어, 아동의 순응에 영향을 미치는 선행 요인들을 탐색한 연구들이 대부분이며, 아동의 순응이 적응 및 발달에 미치는 영향에 대해 다룬 연구 는 매우 드물다. 하지만 최근 국내의 종단 연구에서 유아기 아 동의 불순응과 외현화 문제행동 간의 관계가 다루어졌는데, 3 세 때 불순응은 4 세 때 외현화 문제행동과 유의한 상관이 나타 나지 않았으나, 4 세 때 불순응은 4 세 때 외현화 문제행동과 정 적 상관이 나타났다(H. Song, 2018). 아동의 순응과 외현화 문 제행동 간의 관계를 살펴본 국내외 선행 연구들을 기초로 아 동의 낮은 순응성이 외현화 문제행동 발달의 전조가 되리라 가정해볼 수 있으며, 본 연구는 걸음마기 아동을 대상으로 두 변인 간의 관계를 확인하였다. 걸음마기 아동은 자기조절을 배우는 초기 과정으로서 양육자의 규칙이나 기대에 따르는 순 응 행동을 나타내는데, 이 시기 낮은 순응성은 아동이 상황에 맞게 자신의 행동을 조절하는 능력을 발달시키지 못하였음을 뜻하므로 이는 다른 사람에 대해 적대적이고 파괴적인 행동으 로 이어질 수 있을 것이다. 걸음마기 순응이 유아기 자기통제 로 발달함을 검증한 최근의 국외 연구(Feng et al., 2017)는 이러 한 가능성을 지지한다.

이상에서 살펴본 것과 같이 어머니의 양육행동과 아동의 순응 간의 관련성 그리고 아동의 순응과 외현화 문제행동 간 의 관련성을 토대로, 어머니의 양육행동이 걸음마기 아동의 순응을 매개로 외현화 문제행동에 영향을 미치리라 짐작해 볼 수 있다. 하지만 세 변인 간의 관계를 다룬 선행 연구들은 어머니의 양육행동과 아동의 외현화 문제행동 간의 관계에 서 순응의 매개적 역할에 대해 고려하지 않은 채, 단지 각 변 인 간의 관계를 살펴보는 것에 그치고 있다(Chen et al., 2002; Kochanska \& Kim, 2013). 아동의 순응이 자기조절의 초기 형 태임에 근거할 때(Kopp, 1982), 양육행동이 아동의 자기조절 을 통해 간접적으로 외현화 문제행동에 미치는 영향을 확인한 국내외 선행 연구들은 본 연구의 가정을 뒷받침해준다. 예를 들어, 양육행동과 유아기 아동의 일과(routine), 자기조절 및 외현화 문제행동 간의 관계를 살펴본 국외의 연구에서는 주양 육자의 긍정적 양육행동이 3-5세 아동의 자기조절을 통해 간 
접적으로 외현화 문제행동에 영향을 미쳤다(Bater \& Jordan, 2017). 또한, 어머니의 긍정적 정서 표현성과 부정적 정서 표 현성은 각각 55-79개월 아동의 조절을 매개로 외현화 문제행 동에 영향을 주었다(Eisenberg et al., 2001). 국내의 연구에서도 3-5세 유아기 아동의 자기통제가 어머니의 애정 또는 심리적 통제와 외현화 문제행동 간의 관계를 부분 매개함을 밝혔다 (Sung \& Han, 2015). 이처럼 선행 연구들은 주로 유아기 아동 을 대상으로 자기조절이 어머니의 양육행동과 외현화 문제행 동 간의 관계를 설명할 수 있음을 확인하였는데, 본 연구는 걸 음마기 아동을 대상으로 자기조절이 나타나는 초기 형태인 순 응이 양자 간의 관계에서 매개적 역할을 하는지에 대해 알아 보았다.

한편, 다수의 국내외 선행 연구들은 어머니의 양육행동 과 외현화 문제행동 간에도 밀접한 관련성을 보고한다. 걸음 마기 아동을 대상으로 두 변인 간의 관계를 살펴본 연구들에 서는 어머니의 온정적 및 반응적 양육행동과 걸음마기 아동 의 공격성은 부적 상관이(Brook, Zheng, Whiteman, \& Brook, 2001; Um \& Park, 2006), 어머니의 거부적 및 통제적 양육행 동과 걸음마기 아동의 공격성은 정적 상관이 나타났다(Brook et al., 2001; B. Park, 2013; Um \& Park, 2006). 또한, 공격성이 나 외현화 문제행동을 많이 보이는 걸음마기 아동의 어머니 는 자녀의 부적절한 행동에 대해 달래거나 항복하는 것과 같 이 느슨한(lax) 훈육과 소리를 지르거나 비난하는 것과 같이 분 노를 표현하며 과잉 반응하는(overreactive) 훈육을 보다 더 나 타내었다(Del Vecchio \& O'Leary, 2006; O’Leary, Slep, \& Reid, 1999). 뿐만 아니라 걸음마기에서 유아기로의 종단 연구들 에서도 유사한 결과들이 보고되었는데, 걸음마기 때 어머니 의 반응적 양육행동 또는 정보 제공이나 제안, 설명하는 양육 행동(low-power parenting)은 유아기 아동의 외현화 문제행동 과 부적 상관이 있었고(Kochanska \& Kim, 2013; Wang, Chen, Chen, Cui, \& Li, 2006), 걸음마기 때 어머니의 힘 행사적 양육 행동(power assertion) 또는 설명 없이 금지나 요구, 명령하는 양 육행동(high-power parenting)은 유아기 아동의 공격성 및 외현 화 문제행동과 정적 상관이 있었다(Chen et al., 2002; Wang et al., 2006). 이러한 선행 연구들을 토대로 어머니의 양육행동이 걸음마기 아동의 외현화 문제행동에 직접적으로도 영향을 미 치리라 예측할 수 있는데, 어머니의 긍정적 양육행동은 걸음 마기 아동의 외현화 문제행동과 부적 관련성을, 어머니의 부 정적 양육행동은 걸음마기 아동의 외현화 문제행동과 정적 관 련성을 보일 것으로 사료된다. 걸음마기 아동의 외현화 문제 행동은 유아기까지 상당히 안정적인 경향이 있으며(O’Leary et al., 1999; Shaw et al., 1998; Smith et al., 2004), 이는 유아기를 거쳐 아동기나 청소년기까지도 지속적인 영향을 줄 수 있을 것이다(Bornstein, Hahn, \& Haynes, 2010; Heller, Baker, Henker, \& Hinshaw, 1996). 또한, 아동 초기의 외현화 문제행동은 이후 정서사회적 적응에서의 어려움을 야기할 수도 있다(Patterson, DeBaryshe, \& Ramsey, 1989). 그럼에도 불구하고 걸음마기 시 기의 외현화 문제행동은 유아기 이후의 발달단계에 비해 연구 자들로부터 상대적으로 적은 관심을 받아왔으므로, 이에 대한 연구의 필요성이 강조된다.

종합하면, 본 연구는 어머니의 양육행동, 걸음마기 아동의 순응 및 외현화 문제행동 간의 경로를 알아보고자 하였다. 어 머니의 양육행동이 걸음마기 아동의 외현화 문제행동에 영향 을 미치는 과정에 대한 이해를 넓히고자, 양자 간의 관계에서 걸음마기 아동의 순응의 매개적 역할에 대해 탐색하였다. 구 체적으로 어머니의 양육행동이 걸음마기 아동의 외현화 문제 행동에 미치는 직접적 영향과 걸음마기 아동의 순응을 매개로 미치는 간접적 영향에 대해 살펴보았다. 본 연구의 연구문제 와 연구모형(Figure 1)은 다음과 같다.

\section{연구문제 1}

어머니의 양육행동은 걸음마기 아동의 외현화 문제행동에 직 접적 영향을 미치는가?

\section{연구문제 2}

어머니의 양육행동은 걸음마기 아동의 순응을 매개로 외현화 문제행동에 간접적 영향을 미치는가?

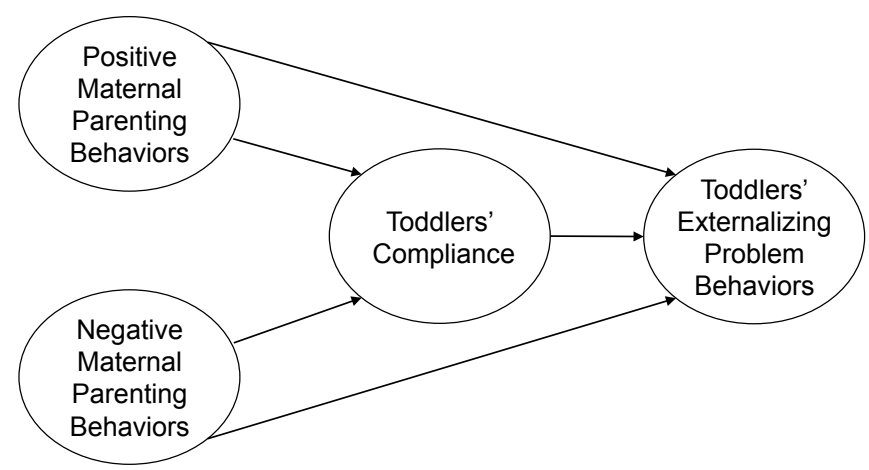

Figure 1. Pathways from maternal parenting behaviors to toddlers' externalizing problem behaviors through compliance. 


\section{Methods}

\section{연구대상}

본 연구는 18-36개월 걸음마기 아동 432명과 그들의 어머니 들을 대상으로 하였으며, 어머니 보고로 자료가 수집되었다. 본 연구대상의 사회인구학적 특성에 대해 살펴보면, 걸음마 기 아동의 경우 성별은 남아가 208 명(48.1\%), 여아가 224 명 (51.9\%)이었으며, 출생순위는 첫째가 273 명 $(63.2 \%)$, 둘째가 138 명(31.9\%), 셋째가 21 명(4.9\%)이었다. 어머니의 경우 연 령은 만 23-45세로 평균 만 34.2세( $S D=3.6)$ 였으며, 만 30-34 세가 186 명(43.1\%)으로 가장 많았고, 그 다음은 만 35-39세가 177 명(41.0\%)으로 많았다. 교육수준은 대학교 졸업이 233명 (53.9\%)으로 가장 높은 비율을 차지하였고, 그 다음은 전문대 졸업 또는 대학교 중퇴가 103명(23.8\%), 대학원 이상이 58명 (13.4\%), 고등학교 중퇴 또는 졸업이 38 명(8.8\%)이었다. 직업 은 일반사무직 혹은 보안업무 종사자가 136명(31.5\%)으로 가 장 많았고, 그 다음은 전업주부가 127 명 $(29.4 \%)$, 회사원, 은행 원, 공무원 및 교사가 97 명 $(22.5 \%)$, 전문직이 44명(10.2\%) 순 이었다. 거주 지역은 서울특별시가 125 명(28.9\%), 부산, 인천, 광주, 대구, 대전, 울산 등 광역시와 세종특별자치시가 109명 (25.2\%), 경기도가 104 명 $(24.1 \%)$, 경상도가 41 명 $(9.5 \%)$, 전라 도가 26 명 $(6.0 \%)$ 순이었다.

\section{연구도구}

\section{어머니의 양육행동}

어머니의 양육행동을 측정하기 위해 Zimmer-Gembeck, Webb, Thomas와 Klag (2015)의 사회적 맥락으로서의 부모 척도걸음마기용(Parents as Social Context Questionnaire-Toddlers [PSCQ-T])을 번안하여 사용하였다. 이는 Skinner, Johnson과 Snyder (2005)가 아동 후기나 청소년기 자녀를 둔 부모를 대상 으로 개발한 사회적 맥락으로서의 부모 척도(Parents as Social Context Questionnaire [PSCQ])를 걸음마기 자녀를 둔 부모에 게 적합하도록 수정한 척도이다. 본 척도는 총 24 문항으로, 6 가지 하위요인들이 각각 4 문항씩으로 구성되어 있다. 각 하위 요인에 대해 살펴보면, 온정(warmth)은 "나는 아이와 함께 무 언가 특별한 것을 한다.”, 구조화(structure)는 "아이에게 내가 기대하는 것이 무엇인지를 확실하게 알려준다.”, 자율성 지지 (autonomy support)는 "스스로 새로운 것을 시도하는 아이의
노력을 지지한다.", 거부(rejection)는 "나는 내 아이를 잘 이해 하지 못하겠다.", 혼란(chaos)은 "아이가 해서는 안 되는 일을 해도 내버려둔다.", 강압(coercion)은 "아이가 무언가를 하도록 하기 위해서 압력을 가해야 한다고 때때로 느낀다.” 등의 문항 이 포함된다. 각 문항은 전혀 그렇지 않다(1점)에서 매우 그렇 다(4점)까지의 4점 리커트식 척도로 측정되었으며, 점수가 높 을수록 어머니가 각 하위요인의 양육행동 특성을 더 많이 나 타냄을 의미한다. Zimmer-Gembeck 등(2015)은 6가지 하위요 인들 중 온정과 구조화, 자율성 지지는 양육행동의 긍정적 차 원에, 거부와 혼란, 강압은 양육행동의 부정적 차원에 속한다 고 구분하고 있다. 또한, 몇몇 선행 연구들(Byrd-Craven, Auer, Granger, \& Massey, 2012; Kennison \& Byrd-Craven, 2015)은 $\mathrm{PSCQ}$ 의 6가지 하위요인들을 긍정적 또는 부정적 차원으로 구분하여 분석하고 있어, 이를 토대로 본 연구는 어머니의 양 육행동을 긍정적 양육행동과 부정적 양육행동으로 나누어 분 석하였다. 어머니의 양육행동의 Cronbach's $\alpha$ 는 온정이 .59, 구 조화가 .52, 자율성 지지가. 71 , 거부가 .70, 혼란이 .65, 강압이 .73이었으며, 긍정적 양육행동과 부정적 양육행동은 각각 .80 과 .86 이었다.

\section{걸음마기 아동의 순응}

걸음마기 아동의 순응을 측정하기 위해 Smetana, Kochanska 와 Chuang (2000)의 규칙 척도(Rules Questionnaire [RQ]) 가 운데 규칙에 대한 아동의 순응을 평가하는 부분을 $\mathrm{Pu}$ (2010) 가 번안하고 J.-S. Lee (2016)가 수정한 것을 사용하였다. 본 척도는 어머니가 자녀에게 부여하는 30 개의 규칙을 자녀가 얼마나 잘 따르는지를 측정하였으며, 총 30 문항으로 안전 건강(prudential), 실제성(pragmatic), 도덕(moral), 사회 관습 (conventional), 개인(personal)의 5 가지 하위요인들로 구성되어 있다. 각 하위요인에 대해 살펴보면, 아동의 안전에 대한 행동 범주를 다루는 안전·건강(4문항)은 “위험한 물건을 만지면 안 된다.”, 소유물 보호에 대한 행동범주를 다루는 실제성(3문항) 은 “책을 찢으면 안 된다.", 대인관계에 대한 행동범주를 다루 는 도덕(4문항)은 “다른 아이의 장난감을 뺏으면 안 된다.”, 복 종과 질서, 음식과 식사시간의 일상, 가족의 일상과 사소한 일 등에 대한 행동범주를 다루는 사회 관습(12문항)은 "부모가 말한 것(지시한 것, 시킨 것)을 해야 한다.”, 자기 보호, 개인 등 에 대한 행동범주를 다루는 개인(7문항)은 "세수나 양치질을 하라고 하면, 해야 한다." 등의 문항이 포함된다. 각 문항은 전 혀 따르지 않는다(1점)에서 항상 따른다(5점)까지의 5점 리커 
트식 척도로 측정되었으며, 점수가 높을수록 걸음마기 아동이 각 영역에서 어머니의 규칙이나 요구를 잘 따름을 의미한다. 걸음마기 아동의 순응의 Cronbach's $\alpha$ 는 안전 · 건강이 .83 , 실 제성이 .75 , 도덕이 .85 , 사회 관습이 .87, 개인이 .64이었으며, 순응 전체는 .92이었다.

\section{걸음마기 아동의 외현화 문제행동}

걸음마기 아동의 외현화 문제행동을 측정하기 위해 BriggsGowan과 Carter (1998)의 영아기 및 걸음마기 아동의 사회.정 서적 평가 척도(Infant-Toddler Social and Emotional Assessment [ITSEA])를 Na, Yee와 Han (2006)이 번안한 척도 가운데 외 현화 문제행동에 해당하는 33 문항을 사용하였다. ITSEA는 $12-36$ 개월 아동의 사회정서적 문제와 유능성에 대해 부모가 평가할 수 있도록 개발된 척도로, 원래는 외현화 문제행동, 내 면화 문제행동, 조절문제, 부적응 행동 및 유능성에 대해 측 정한다. 이 중 외현화 문제행동은 활동성(activity), 공격성/반 항(aggression/defiance), 또래공격성(peer aggression), 부정적 정 서표현(negative emotional reactivity)의 4 가지 하위요인들로 구 성되어 있다. 각 하위요인에 대해 살펴보면, 활동성(8문항)은 "주의산만하고 가만히 앉아있지 못한다.", 공격성/반항(12문 항)은 "아이나 성인을 때리고, 밀치고, 차거나 무는 행동을 한 다.”, 또래공격성(8문항)은 "다른 아이에게서 장난감을 빼앗는 다.”, 부정적 정서표현(5문항)은 “화를 자주 내거나 쉽게 뾰로 통해진다.” 등의 문항이 포함된다. 각 문항은 전혀 그렇지 않 다(1점)에서 자주 그렇다(3점)까지의 3점 리커트식 척도로 측 정되었으며, 점수가 높을수록 걸음마기 아동이 각 하위요인의 외현화 문제행동을 더 많이 나타냄을 의미한다. 걸음마기 아 동의 외현화 문제행동의 Cronbach's $\alpha$ 는 활동성이 .86, 공격성/ 반항이 .90 , 또래공격성이 .88, 부정적 정서표현이 .81이었으 며, 외현화 문제행동 전체는 .94이었다.

\section{연구절차}

본 연구는 이화여자대학교 생명윤리심의위원회의 승인(IRBNO. 164-32)을 받은 후 온라인 리서치 업체에 의뢰하여 연구 대상자 모집을 대행하고 설문조사를 실시하였다. 리서치 업체 는 100 만명 이상의 패널을 보유하고 있으며, 전체 패널을 대 상으로 연구주제를 공지하고 20-45세에 해당하는 여성 패널 에게는 연구주제에 대해 알리는 이메일을 발송하였다. 설문조 사에 참여하기를 원하는 패널은 '조사 참여하기' 버튼을 누른
후, 자신의 성별과 출생년도, 자녀 유무와 자녀수, 자녀의 성별 과 출생년월 등을 입력하도록 하였다. 18-36개월 걸음마기 자 녀를 두었다고 응답한 어머니들에게 본 연구의 목적과 방법, 예상되는 위험과 이득, 보상, 개인정보 제공 및 보호 등에 관한 내용이 포함된 연구 참여 설명서를 제시하였다. 어머니들은 이러한 설명서를 읽은 후 참여를 원할 경우 설문조사에 응하 겠다는 '동의함' 버튼을 누르고 설문에 응답하였다. 이러한 과 정을 통해 2018년 8월에 18-36개월 걸음마기 자녀를 둔 어머니 495명이 설문조사에 참여하였으며, 이 중 불성실한 응답자 63 명을 제외하고 432 명의 자료를 본 연구의 분석에 사용하였다.

\section{자료분석}

수집된 자료는 SPSS 21.0 (IBM Co., Armonk, NY) 프로그램과 AMOS 22.0 (IBM Co., Armonk, NY) 프로그램을 사용하여 분 석하였다. 먼저 연구대상의 사회인구학적 특성을 살펴보기 위해 빈도와 백분율, 평균과 표준편차를 산출하였고, 연구도 구의 신뢰도를 확인하기 위해 Cronbach's $\alpha$ 를 산출하였다. 다 음으로 어머니의 양육행동과 걸음마기 아동의 순응 및 외현 화 문제행동의 기술통계와 세 변인 간의 관계에 대한 Pearson 의 적률상관계수를 산출하였다. 마지막으로 어머니의 양 육행동과 걸음마기 아동의 순응이 외현화 문제행동에 영향 을 미치는 경로를 검증하기 위해 구조방정식 모형(structural equation modeling) 분석을 실시하였다. 모형의 적합도를 평가 하기 위해 $\chi^{2}$ 와 함께 상대적 적합도 지수인 Normed Fit Index (NFI), Tucker-Lewis Index (TLI), Comparative Fit Index (CFI) 와 절대 적 적합도 지수인 Goodness of Fit Index (GFI), Root Mean Square Error of Approximation (RMSEA)를 살펴보았 다. 매개효과의 유의성을 검증하기 위해서는 부트스트래핑 (bootstrapping) 방법을 사용하였다.

\section{Results}

\section{상관관계 분석}

구조방정식 모형을 분석하기에 앞서, 연구변인들의 기술통계 와 Pearson의 적률상관계수를 산출하였다(Table 1). 어머니의 양육행동의 하위요인들과 긍정적 및 부정적 양육행동 점수는 평균 2.04 3.10 $(S D=0.34 \sim 0.54)$, 걸음마기 아동의 순응의 하위요인들과 전체 점수는 평균 $3.07 \sim 3.55(S D=0.51 \sim 0.81)$, 
걸음마기 아동의 외현화 문제행동의 하위요인들과 전체 점수 는 평균 $1.22 \sim 1.82(S D=0.32 \sim 0.49)$ 로 나타났다. 왜도와 첨 도는 각각 - $0.49 \sim 2.28$ 과 $-0.73 \sim 5.27$ 로, 왜도와 첨도의 절대값 이 각각 3 미만과 10 미만이어야 한다는 정규성 가정의 기준 (Kline, 2015)을 충족하였다.

연구변인들 간의 상관관계는 대체로 유의하였다. 먼저 어 머니의 양육행동과 걸음마기 아동의 외현화 문제행동 간의 관 계를 살펴보면, 어머니의 긍정적 양육행동은 걸음마기 아동 의 외현화 문제행동과 부적 상관을 보인 반면 $(r=-.15, p<.01)$, 어머니의 부정적 양육행동은 걸음마기 아동의 외현화 문제행 동과 정적 상관을 보였다 $(r=.59, p<.001)$. 구체적으로 각 하 위요인들 간의 관계를 살펴본 결과, 어머니의 온정은 걸음마 기 아동의 활동성 및 공격성/반항과, 어머니의 구조화는 걸음 마기 아동의 공격성/반항 및 또래공격성과, 어머니의 자율성 지지는 걸음마기 아동의 활동성, 공격성/반항 및 또래공격성 과 부적 상관이 나타났으며(온정: $r s=-.16 \sim-.12, p<.05$ 또는 $p<.01$; 구조화: $r s=-.10, p<.05$; 자율성 지지: $r s=-.18 \sim-.11, p$ $<.05, p<.01$ 또는 $p<.001)$, 어머니의 거부, 혼란 및 강압은 걸 음마기 아동의 활동성, 공격성/반항, 또래공격성 및 부정적 정 서표현 모두와 정적 상관이 나타났다(거부: $r s=.39 \sim .52, p<$ .001 ; 혼란: $r s=.37 \sim .41, p<.001$; 강압: $r s=.34 \sim .50, p<.001$ ). 즉, 어머니가 긍정적 양육행동을 적게 보이거나 부정적 양육 행동을 많이 보일수록 걸음마기 아동은 외현화 문제행동을 더 많이 나타내는 경향이 있었다.

다음으로 어머니의 양육행동과 걸음마기 아동의 순응 간의 관계를 살펴보면, 어머니의 긍정적 양육행동은 걸음마기 아동 의 순응과 정적 상관을 보인 반면 $(r=.26, p<.001)$, 어머니의 부정적 양육행동은 걸음마기 아동의 순응과 부적 상관을 보였 다 $(r=-.38, p<.001)$. 구체적으로 각 하위요인들 간의 관계를 살펴본 결과, 어머니의 온정은 걸음마기 아동의 안전.건강, 실 제성, 도덕, 사회 관습 및 개인에 관한 순응 모두와, 어머니의 구조화 및 자율성 지지는 걸음마기 아동의 안전·건강, 실제성, 도덕 및 사회 관습에 관한 순응과 정적 상관이 나타났으며(온 정: $r s=.17 \sim .29, p<.001$; 구조화: $r s=.11 \sim .19, p<.05, p<.01$ 또는 $p<.001$; 자율성 지지: $r s=.13 \sim .25, p<.01$ 또는 $p<.001$ ), 어머니의 거부, 혼란 및 강압은 걸음마기 아동의 안전.건강, 실 제성, 도덕, 사회 관습 및 개인에 관한 순응 모두와 부적 상관 이 나타났다(거부: $r s=-.30 \sim-.21, p<.001$; 혼란: $r s=-.35 \sim-.19$, $p$ <.001; 강압: $r s=-.34 \sim-.17, p<.01$ 또는 $p<.001)$. 즉, 어머 니가 긍정적 양육행동을 많이 보이거나 부정적 양육행동을 적 게 보일수록 걸음마기 아동은 순응을 더 많이 나타내는 경향
이 있었다.

마지막으로 걸음마기 아동의 순응과 외현화 문제행동 간의 관계를 살펴보면, 걸음마기 아동의 순응은 외현화 문제행동과 부적 상관을 보였다 $(r=-.34, p<.001)$. 구체적으로 각 하위요 인들 간의 관계를 살펴본 결과, 걸음마기 아동의 안전·건강, 실 제성 및 도덕에 관한 순응은 활동성, 공격성/반항, 또래공격성 및 부정적 정서표현 모두와, 걸음마기 아동의 사회 관습 및 개 인에 관한 순응은 활동성, 공격성/반항 및 부정적 정서표현과 부적 상관이 나타났다(안전·건강: $r s=-.36 \sim-.21, p<.001$; 실 제성: $r s=-.28 \sim-.10, p<.05, p<.01$ 또는 $p<.001$; 도덕: $r s=-.29$ $\sim-.19, p<.001$; 사회 관습: $r s=-.28 \sim-.23, p<.001$; 개인: $r s=$ $-.19 \sim-.11, p<.05, p<.01$ 또는 $p<.001)$. 즉, 걸음마기 아동은 순응을 적게 보일수록 외현화 문제행동을 더 많이 나타내는 경향이 있었다.

\section{측정모형 분석}

어머니의 양육행동과 걸음마기 아동의 순응 및 외현화 문제행 동을 측정하는 측정변인들이 잠재변인들을 잘 설명하는지를 살펴보기 위해 확인적 요인분석(confirmatory factor analysis)을 실시하였으며, 최대우도법(maximum likelihood estimation)을 사용하여 분석하였다. 그 결과, 적합도 지수는 $\chi^{2}=323.38(d f=$ $84, p<.001), \chi^{2} / d f=3.85, \mathrm{NFI}=.89, \mathrm{TLI}=.90, \mathrm{CFI}=.92$, GFI $=.91, \mathrm{RMSEA}=.08(90 \% \mathrm{CI}[.07, .09])$ 로 나타났다(Table 2). $\chi^{2}$ 는 표본의 크기에 민감하여 표본의 크기가 커지면 모형이 기 각되기 쉬우므로 다른 적합도 지수를 함께 고려해야 하는데, NFI, TLI, CFI, GFI는 .90 이상(Hong, 2000), RMSEA는 .08이 하(Browne \& Cudeck, 1993)를 적절한 적합도의 기준으로 판 단함에 따라 본 연구의 측정모형은 NFI가 적절한 적합도의 기 준에 다소 부합하지 못하였다. 이에 수정지수를 기초로, 걸음 마기 아동의 순응에 대한 측정변인들 중 사회 관습의 오차와 개인의 오차 간에 공분산을 설정하였다. 수정한 측정모형의 적합도 지수는 $\chi^{2}=301.67(d f=83, p<.001), \chi^{2} / d f=3.64, \mathrm{NFI}$ $=.90, \mathrm{TLI}=.90, \mathrm{CFI}=.92, \mathrm{GFI}=.91, \mathrm{RMSEA}=.08(90 \% \mathrm{CI}$ $[.07, .09])$ 로 나타나(Table 2), 적절한 적합도의 기준을 모두 충 족하였다. 또한, 잠재변인에서 측정변인으로의 요인부하량 $(\beta)$ 은 .50 .94로 절대값이 .40 이상이어야 한다는 기준(J. J. Song, 2015)에 모두 부합하였고, Critical Ratio (C.R.) 값 역시 모두 $\alpha$ $=.001$ 수준에서 유의하여(Table 3), 측정변인들이 잠재변인들 을 적절하게 설명하는 것으로 나타났다. 


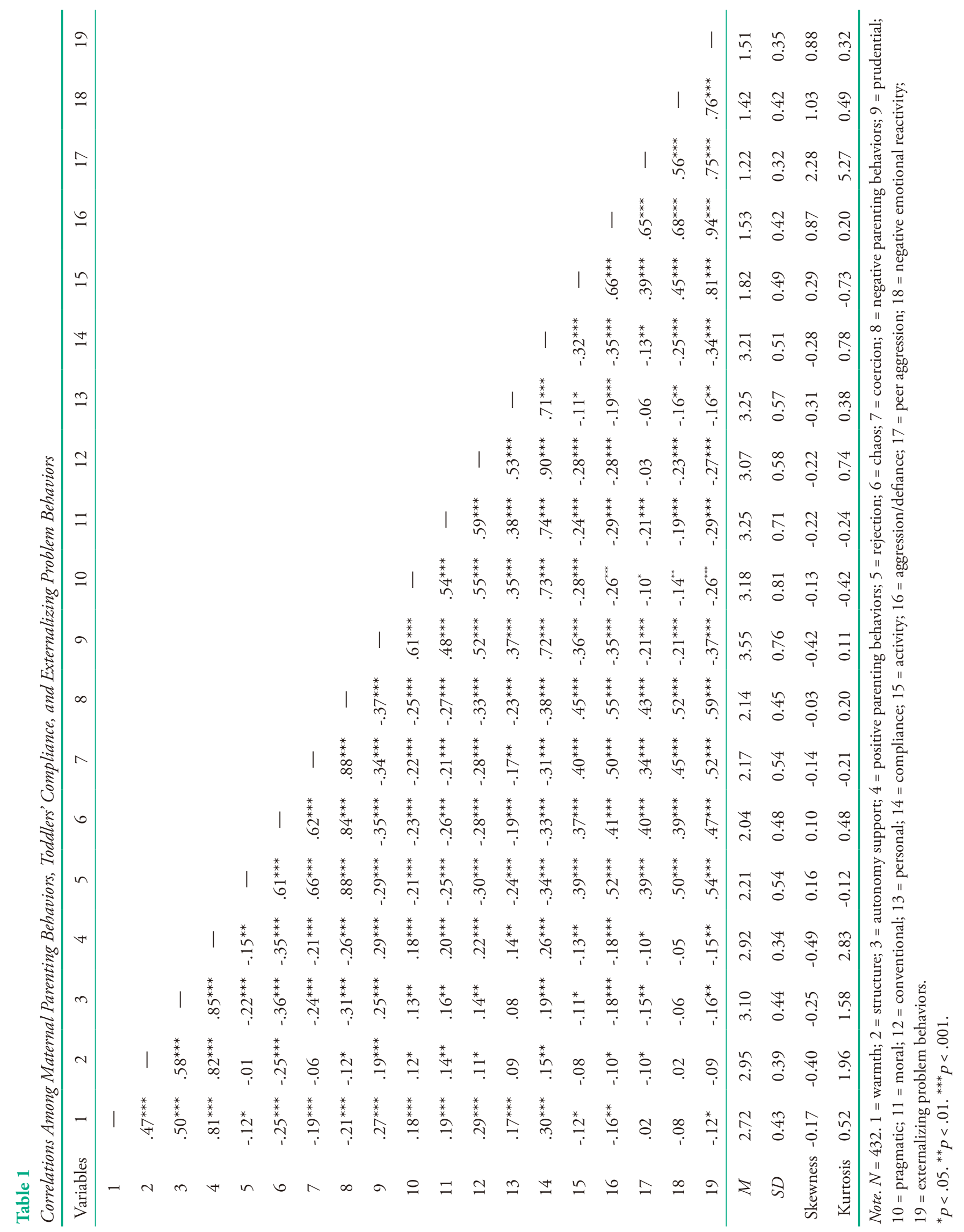


Table 2

Fit Indices of the Measurement Model

\begin{tabular}{ccccccccc}
\hline \multicolumn{1}{c}{ Model } & $\chi^{2}$ & $d f$ & $\chi^{2} / d f$ & NFI & TLI & CFI & GFI & RMSEA (LO90 HI90) \\
\hline Initial model & $323.38^{* * *}$ & 84 & 3.85 & .89 & .90 & .92 & .91 & $.08(.07 \sim .09)$ \\
Modified model & $301.67^{* * *}$ & 83 & 3.64 & .90 & .90 & .92 & .91 & $.08(.07 \sim .09)$ \\
\hline
\end{tabular}

Note. $N=432$.

${ }^{* * *} p<.001$.

Table 3

Factor Loadings of the Measurement Model

Variables

Positive maternal parenting behaviors

Warmth

Structure

Autonomy support

Negative maternal parenting behaviors

Rejection

Chaos

Coercion

Toddlers' compliance

Prudential

Pragmatic

Moral

Conventional

Personal

Toddlers' externalizing problem behaviors

Activity

Aggression/defiance

Peer aggression

Negative emotional reactivity

Note. $N=432$.

${ }^{* * *} p<.001$.

\section{구조모형 분석}

어머니의 양육행동과 걸음마기 아동의 순응이 외현화 문제행 동에 영향을 미치는 경로를 살펴보기 위해 구조모형을 분석한 결과, 적합도 지수는 $\chi^{2}=301.67(d f=83, p<.001), \chi^{2} / d f=3.64$, $\mathrm{NFI}=.90, \mathrm{TLI}=.90, \mathrm{CFI}=.92, \mathrm{GFI}=.91, \mathrm{RMSEA}=.08(90 \%$ $\mathrm{CI}[.07, .09])$ 로 나타나, 적절한 적합도의 기준을 모두 충족하 였다. 어머니의 양육행동과 걸음마기 아동의 순응이 외현화 문제행동에 영향을 미치는 경로를 구체적으로 살펴보면 다음 과 같다(Table 4, Figure 2). 먼저 어머니의 양육행동이 걸음마 기 아동의 외현화 문제행동에 영향을 미치는 직접 경로와 관

$B \quad \beta$

SE

C.R.

$1.00 \quad .65$

$.98 \quad .71$

1.25

.80

.09

$10.96^{* * *}$

.11

$10.99^{* * *}$

1.00

.81

.83

.99

.76

.05

$15.92^{* * *}$

.81

.06

$16.84^{* * *}$

$1.00 \quad .74$

$1.08 \quad .76$

.08

$14.21^{* * *}$

.90

.71

.07

$13.50^{* * *}$

.76

.74

.50

.06

$13.95^{* * *}$

.05

$9.28^{* * *}$

1.00

.69

1.16

.65

.94

.07

$16.45^{* * *}$

.68

.05

$13.13^{* * *}$

.92 $13.95^{\text {*** }}$

련하여, 어머니의 긍정적 양육행동은 걸음마기 아동의 외현화 문제행동에 유의한 영향을 미치지 않은 반면 $(\beta=.05, p>.05)$, 어머니의 부정적 양육행동은 걸음마기 아동의 외현화 문제행 동에 유의한 정적 영향을 미쳤다 $(\beta=.62, p<.001)$. 즉, 어머니 가 거부, 혼란 및 강압과 같은 부정적 양육행동을 많이 보일수 록 걸음마기 아동은 외현화 문제행동을 더 많이 나타내었다. 다음으로 어머니의 양육행동이 걸음마기 아동의 순응을 매개 로 외현화 문제행동에 영향을 미치는 간접 경로와 관련하여, 어머니의 긍정적 양육행동은 걸음마기 아동의 순응에 유의한 정적 영향 $(\beta=.19, p<.01)$ 을, 어머니의 부정적 양육행동은 걸 음마기 아동의 순응에 유의한 부적 영향 $(\beta=-.39, p<.001)$ 을 
Table 4

Path Estimates in the Structural Model

\begin{tabular}{llrrrr}
\hline & Path between variables & $B$ & $\beta$ & $S E$ & C.R. \\
\hline Positive maternal parenting behaviors & $\rightarrow$ Toddlers' externalizing problem behaviors & .05 & .05 & .05 & 1.02 \\
Negative maternal parenting behaviors & $\rightarrow$ Toddlers' externalizing problem behaviors & .48 & .62 & .05 & $9.19^{* * *}$ \\
Toddlers' compliance & $\rightarrow$ Toddlers' externalizing problem behaviors & -.09 & -.16 & .03 & $-2.85^{* *}$ \\
Positive maternal parenting behaviors & $\rightarrow$ Toddlers' compliance & .31 & .19 & .10 & $3.13^{* *}$ \\
Negative maternal parenting behaviors & $\rightarrow$ Toddlers' compliance & -.51 & -.39 & .08 & $-6.33^{* * *}$ \\
\hline
\end{tabular}

Note. $N=432$.

${ }^{* *} p<.01{ }^{* * *} p<.001$.

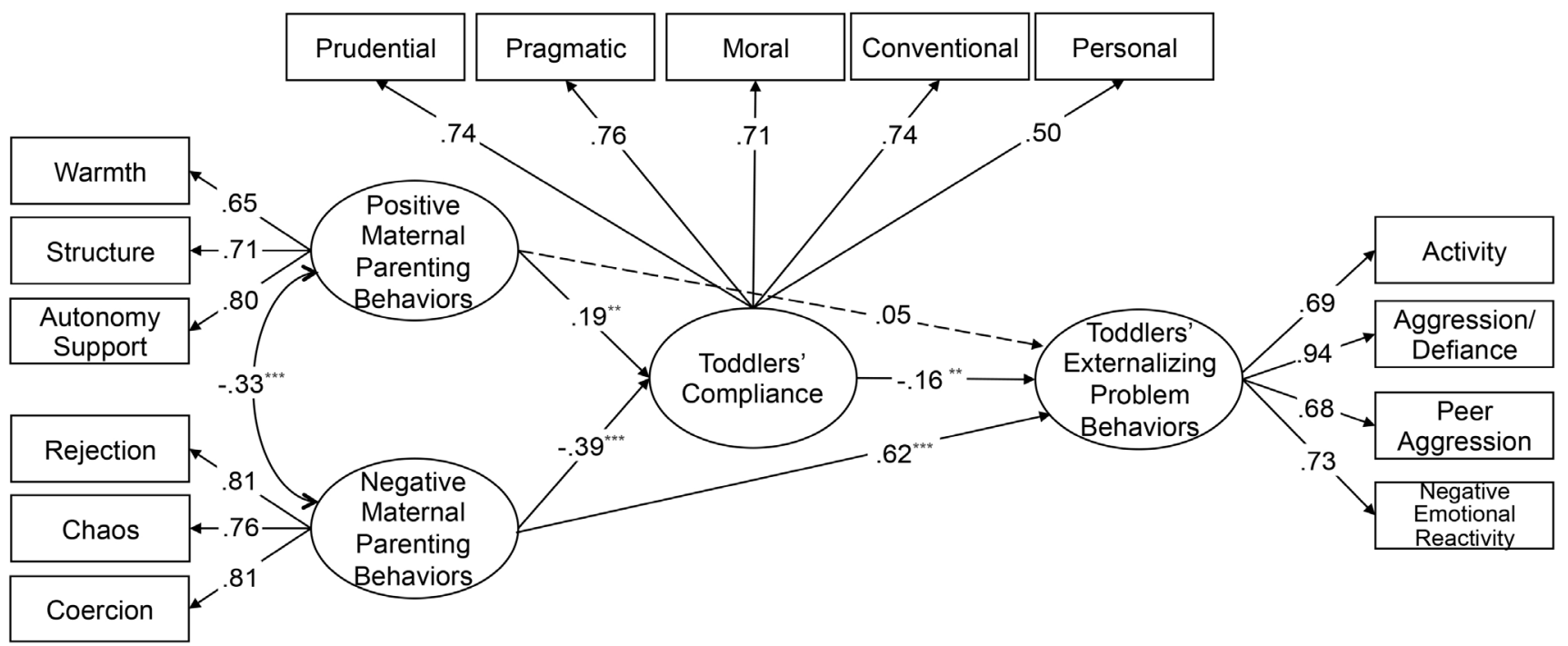

Figure 2. Direct and indirect paths from maternal parenting behaviors to toddlers' externalizing problem behaviors.

${ }^{* *} p<.01 .{ }^{* * *} p<.001$.

미쳤으며, 걸음마기 아동의 순응은 외현화 문제행동에 유의한 부적 영향을 미쳤다 $(\beta=-.16, p<.01)$. 즉, 어머니가 온정, 구조 화 및 자율성 지지와 같은 긍정적 양육행동을 적게 보이거나 거부, 혼란 및 강압과 같은 부정적 양육행동을 많이 보일수록 걸음마기 아동은 순응을 적게 나타내었으며, 이는 외현화 문 제행동을 더 많이 보이는 것으로 이어졌다.

어머니의 양육행동이 걸음마기 아동의 외현화 문제행동에 영향을 미치는 간접효과가 유의한지를 부트스트래핑 방법을 통해 살펴본 결과, 어머니의 긍정적 양육행동 $(\beta=-.03, p<.01)$ 과 부정적 양육행동 $(\beta=.06, p<.05)$ 모두 걸음마기 아동의 순 응을 매개로 외현화 문제행동에 영향을 미치는 간접효과는 유 의하였다. 또한, 내생변인이 외생변인에 의해 설명되는 정도 인 다중상관치(squared multiple correlations)를 살펴본 결과, 어 머니의 긍정적 및 부정적 양육행동과 걸음마기 아동의 순응은 걸음마기 아동의 외현화 문제행동을 $46.5 \%$ 설명하였으며, 어
머니의 긍정적 및 부정적 양육행동은 걸음마기 아동의 순응을 $23.6 \%$ 설명하였다.

\section{Discussion}

본 연구는 어머니의 양육행동, 걸음마기 아동의 순응 및 외현 화 문제행동 간의 경로를 확인하고자, 어머니의 양육행동이 걸음마기 아동의 외현화 문제행동에 미치는 직접적 영향과 걸 음마기 아동의 순응을 매개로 미치는 간접적 영향에 대해 살 펴보았다. 본 연구의 주요 결과를 요약하고 논의하면 다음과 같다.

첫째, 어머니의 양육행동이 걸음마기 아동의 외현화 문제 행동에 영향을 미치는 직접 경로와 관련하여, 어머니의 부정 적 양육행동만이 걸음마기 아동의 외현화 문제행동에 직접적 
으로 영향을 미쳤다. 즉, 어머니가 거부, 혼란, 강압과 같은 부 정적 양육행동을 많이 보일수록 걸음마기 아동은 활동성, 공 격성/반항, 또래공격성, 부정적 정서표현과 같은 외현화 문제 행동을 더 많이 나타내었다. 선행 연구들도 대체로 본 연구의 결과와 유사하게 어머니의 부정적 양육행동이 자녀의 높은 외 현화 문제행동과 관련됨을 보고하고 있다. 구체적으로 걸음 마기 시기 어머니의 거부나 통제, 강압은 자녀의 공격성 및 외 현화 문제행동과 정적인 관계가 있음이 횡단적(Brook et al., 2001; B. Park, 2013; Um \& Park, 2006) 그리고 종단적(Chen et al., 2002; Combs-Ronto et al., 2009; Wang et al., 2006) 연구 설 계를 통해 입증되었다. 또한, 어머니가 간섭(Eisenberg, Taylor, Widaman, \& Spinrad, 2015)이나 과잉 반응적 훈육(O'Leary et al., 1999)을 많이 보일수록 걸음마기 아동은 외현화 문제행동 을 더 나타내었다. 이러한 결과를 해석해보면, 어머니의 거부 나 강압의 경우 자녀로 하여금 좌절이나 분노와 같은 부정적 정서를 유발하거나 자녀에게 부적절한 모델이 됨으로써 외현 화 문제행동을 증가시켰을 가능성이 있다. 또한, 혼란의 경우 자녀의 행동에 대해 어머니가 적절한 규칙이나 제한을 설정하 지 않아, 걸음마기 시기 급격하게 발달하는 자기조절능력을 저해하여 외현화 문제행동으로 나타났을 가능성이 있다.

부정적 양육행동과 달리, 온정, 구조화, 자율성 지지와 같은 어머니의 긍정적 양육행동의 경우 걸음마기 아동의 외현화 문 제행동과의 상관관계에서는 몇몇 유의한 부적 상관이 발견되 었으나, 어머니의 부정적 양육행동과 걸음마기 아동의 순응 및 외현화 문제행동을 함께 고려한 구조방정식 모형에서는 걸 음마기 아동의 외현화 문제행동에 직접적으로 영향을 미치지 않았다. 어머니의 긍정적 양육행동과 걸음마기 아동의 외현화 문제행동 간의 관계를 다룬 선행 연구들을 살펴보면, 어머니 의 긍정적 양육행동과 걸음마기 아동의 공격성 및 외현화 문 제행동 간에 부적 상관을 보고한 연구들도 있는 반면(Brook et al., 2001; Mendez, Durtschi, Neppl, \& Stith, 2016; Um \& Park, 2006), 유의한 상관을 밝히지 못한 연구들도 있다(B. Park, 2013; Smith et al., 2004). 또한, 걸음마기 남아를 대상으로 두 변인 간의 관계를 양방향적으로 살펴본 연구에서는 걸음마기 남아의 외현화 문제행동이 어머니의 지지에 미치는 부적 영향 만을 발견하고, 어머니의 지지나 긍정적 훈육이 걸음마기 남 아의 외현화 문제행동에 미치는 유의한 영향은 발견하지 못하

였다(Verhoeven, Junger, van Aken, Deković, \& van Aken, 2010). 이와 같이 어머니의 긍정적 양육행동과 걸음마기 아동의 외 현화 문제행동 간의 관계를 다룬 선행 연구들이 다소 비일관 적인 결과를 보고하는 것에 대해 두 가지 측면으로 해석해볼
수 있다. Pettit과 Bates (1989)는 6개월부터 4세까지의 종단 연 구를 통해 긍정적 양육행동의 부재가 부정적 양육행동의 존재 만큼 아동의 문제행동에 영향을 미친다고 제안하였는데, 어머 니의 긍정적 양육행동의 영향력이 걸음마기 시기에 즉각적으 로 발휘되기보다는 아동이 다른 사람과 관계를 형성하기 시작 하는 유아기 이후에 보다 명확하게 나타날 수도 있을 것이다. 뿐만 아니라 van Aken, Junger, Verhoeven, van Aken과 Deković (2007)의 연구에서 보고한 것과 같이, 어머니의 긍정적 양육행 동과 걸음마기 아동의 외현화 문제행동 간의 관계에 아동의 기질과 같은 제 3 의 변인이 영향을 미칠 수도 있다. 본 연구에 서는 어머니의 긍정적 양육행동과 걸음마기 아동의 외현화 문 제행동 간의 관계를 설명할 수 있는 변인으로서 순응의 매개 적 역할에 대해 살펴보았으며, 후속 연구에서도 양자 간의 관 계를 매개하거나 중재하는 제 3 의 변인들을 지속적으로 탐색 해볼 필요가 있다.

둘째, 어머니의 양육행동이 걸음마기 아동의 순응을 매개 로 외현화 문제행동에 영향을 미치는 간접 경로와 관련하여, 어머니의 긍정적 및 부정적 양육행동은 모두 걸음마기 아동의 순응을 통해 외현화 문제행동에 간접적으로 영향을 미쳤다. 즉, 어머니가 온정, 구조화, 자율성 지지와 같은 긍정적 양육행 동을 덜 보일수록 그리고 어머니가 거부, 혼란, 강압과 같은 부 정적 양육행동을 많이 보일수록 걸음마기 아동은 순응을 적게 나타내었고, 이는 외현화 문제행동을 보다 많이 나타내는 것 으로 연결되었다. 아동의 순응이 초기 자기조절의 원형이 된 다는 점에 근거할 때(Kochanska, Coy, \& Murray, 2001; Kopp, 1982), 본 연구결과는 어머니의 양육행동이 유아기 아동의 자 기통제 혹은 자기조절을 통해 외현화 문제행동에 미치는 간 접적 영향을 보고한 국내외 선행 연구결과들(Bater \& Jordan, 2017; Sung \& Han, 2015)과 유사하다. 또한, 어머니의 긍정적 및 부정적 정서 표현성이 유아기 아동의 조절 능력을 매개로 외현화 문제행동에 미치는 영향을 밝힌 연구(Eisenberg et al., 2001)와도 유사한 맥락이다. 기존의 연구들이 어머니의 양육 행동과 외현화 문제행동 간의 관계에서 유아기 아동의 자기통 제나 자기조절의 매개적 역할을 발견한 것에서 나아가, 본 연 구는 두 변인 간의 관계에서 자기조절의 초기 형태인 걸음마 기 아동의 순응이 매개적 역할을 할 수 있음을 실증적으로 확 인하였다. 본 연구와 선행 연구들의 결과를 종합해볼 때, 자녀 와의 관계에서 자기 자신을 잘 조절할 수 있는 어머니가 자녀 에게 긍정적 양육행동을 더 많이 나타내고 부정적 양육행동을 덜 나타내기 쉬울 것이며, 이러한 어머니는 자녀에게도 높은 자기조절을 기대하여 자녀가 순응성이나 자기조절을 발달시 
키고 결과적으로 외현화 문제행동을 덜 보이는 것으로 이해해 볼 수도 있다.

어머니의 양육행동이 걸음마기 아동의 순응을 통해 외현화 문제행동에 영향을 미치는 간접 경로를 좀 더 구체적으로 어 머니의 양육행동이 걸음마기 아동의 순응에 미치는 영향과 걸 음마기 아동의 순응이 외현화 문제행동에 미치는 영향으로 나 누어 살펴보면 다음과 같다. 먼저 어머니의 양육행동이 걸음 마기 아동의 순응에 영향을 미치는 경로와 관련하여, 온정, 구 조화, 자율성 지지와 같은 어머니의 긍정적 양육행동은 걸음 마기 아동의 순응에 정적 영향을, 거부, 혼란, 강압과 같은 어 머니의 부정적 양육행동은 걸음마기 아동의 순응에 부적 영 향을 미쳤다. 이는 걸음마기 아동을 대상으로 어머니의 긍정 적 양육행동과 자녀의 순응 간에는 정적 관련성을, 어머니의 부정적 양육행동과 자녀의 순응 간에는 부적 관련성을 보고한 국내외 선행 연구결과들(Calkins et al., 1998; Chen et al., 2003; Feldman \& Klein, 2003; Feng et al., 2017; Laurin \& Joussemet, 2017; Lehman et al., 2002; S.-Y. Park \& Shin, 2007; Spinrad et al., 2012)과 일치한다. 특히 본 연구에서는 어머니의 부정적 양육 행동 $(\beta=-.39, p<.001)$ 이 긍정적 양육행동 $(\beta=.19, p<.01)$ 에 비해 걸음마기 아동의 순응에 미치는 영향력이 더 큰 것으로 나타났다. 이는 부모의 양육행동과 2-5세 자녀의 자기조절 간 의 관계를 다룬 연구들을 메타분석한 연구결과(Karreman, van Tuijl, van Aken, \& Deković, 2006)와 유사한 맥락에서 이해할 수 있다. Karreman 등(2006)은 양육행동을 긍정적 통제, 부정 적 통제 및 반응성으로 구분하여 자녀의 자기조절과의 관계를 살펴본 결과, 이 중 자녀에게 강압적이고 적대적이며 자녀를 비난하는 양육행동을 의미하는 부정적 통제가 가장 큰 효과 크기를 보임을 밝혔으며, 자기조절의 하위 범주 중 순응이 부 모의 긍정적 통제와는 정적으로, 부모의 부정적 통제와는 부 적으로 관련됨을 보고하였다. 발달적 측면에서 볼 때 걸음마 기는 운동능력의 발달로 활동반경이 더욱 넓어지고 자율성이 점차 증가하는 시기이다. 이에 주양육자인 어머니는 이전보 다 자녀에게 규칙이나 요구를 더 많이 부여하게 되나, 자녀의 자기주장이 강해지면서 부모-자녀관계에서 갈등 상황이 발생 하기 쉽다. 걸음마기 자녀를 둔 어머니는 자녀의 발달적 특성 에 대한 이해를 기초로 순응 또는 불순응 행동이 발달하는 시 기인 걸음마기 시기에 온정적이고 적절하게 한계를 설정하며 자율성을 지지하는 긍정적 양육행동을 보임으로써 자녀가 어 머니와 협조적인 관계를 형성하도록 도와야 한다. 특히 자녀 양육 시 적절한 제한을 설정하지 않거나 거부적이고 강압적인 부정적 양육행동을 보이지 않도록 주의할 필요가 있다.
다음으로 걸음마기 아동의 순응이 외현화 문제행동에 영 향을 미치는 경로와 관련하여, 걸음마기 아동의 순응은 외현 화 문제행동에 부적 영향을 미쳐, 낮은 수준의 순응을 보이는 걸음마기 아동이 외현화 문제행동을 더 많이 나타내었다. 이 러한 결과는 24 개월 때 걸음마기 아동이 보인 불순응이 36개 월 때 외현화 문제행동과 관련됨을 보고한 Keenan 등(1998)의 연구결과와 일치한다. 또한, 걸음마기 순응이 이후 유아기 외 현화 문제행동을 예측함을 발견한 연구들(Chen et al., 2002; Kuczynski \& Kochanska, 1990)이나 유아기 순응과 외현화 문 제행동 간의 관련성을 밝힌 연구들(Kochanska \& Kim, 2013; Prodromidis, Lamb, Sternberg, Hwang, \& Broberg, 1995; H. Song, 2018)의 결과와도 일맥상통한다. 걸음마기에 나타나는 순응이 양육자의 지시나 요구에 적절하게 자신의 행동을 조절 하는 능력과 관련된다는 점(Kochanska et al., 2001; Kopp, 1982) 을 고려해볼 때, 이 시기 순응에서의 개인차는 부모나 또래와 의 상호작용 시 상대방의 기준이나 목표에 맞춰 자신의 행동 이나 감정을 조절하는 능력과 연관이 있으므로, 아동의 낮은 순응성은 다른 사람과의 관계에서 경험하는 부정적 정서를 잘 조절하지 못하고 이를 외부로 표출하는 외현화 문제행동으로 이어질 수 있을 것이다.

결론적으로 본 연구는 어머니의 온정, 구조화, 자율성 지지 와 같은 긍정적 양육행동은 걸음마기 아동의 순응을 통해 간 접적으로만 외현화 문제행동에 영향을 미치고, 어머니의 거 부, 혼란, 강압과 같은 부정적 양육행동은 직접적으로 뿐만 아 니라 걸음마기 아동의 순응을 통해 간접적으로도 외현화 문제 행동에 영향을 미침을 확인하였다. 높은 수준의 외현화 문제 행동을 보일 경우 또래로부터 수용되지 못하고 거부될 위험 이 높기 때문에(Keane \& Calkins, 2004; Wood, Cowan, \& Baker, 2002), 부모는 자녀의 외현화 문제행동 발달을 예방하기 위해 온정, 구조화, 자율성 지지 등을 보다 많이 나타내고 거부, 혼 란, 강압 등을 덜 나타내는 바람직한 양육행동을 보여야 하며, 이를 통해 자녀의 순응성을 높일 필요가 있다. 걸음마기 아동 이 규칙이나 지시에 대한 순응성, 즉 자기조절의 초기 형태를 습득하는 과정에서 부모는 아동을 정서적으로 지지해주거나 칭찬이나 격려를 통해 아동의 협조적 행동을 강화하거나 아동 에게 긍정적 행동의 모델이 되는 것과 같은 양육행동을 통해 아동이 순응 행동을 학습하도록 도와줄 수 있다. 본 연구에서 는 어머니의 긍정적 양육행동보다 부정적 양육행동이 걸음마 기 아동의 순응과 외현화 문제행동에 미치는 영향력이 상대적 으로 더 크다는 것을 확인하였으며, 이는 가정에서 아동을 사 회화하는 과정에서 특히 부정적 양육행동이 아동이 사회적으 
로 바람직한 행동을 습득하는 것을 방해하고 다른 사람에 대 한 적대적이고 파괴적인 행동을 강화시킬 수 있음을 시사한 다. 또한, 어머니의 부정적 양육행동이 걸음마기 아동의 낮은 순응성을 통해 외현화 문제행동으로 연결될 수 있다는 본 연 구의 결과는 아동 초기에 어머니와 아동 간의 부정적인 상호 작용의 패턴이 확립될 수도 있음을 의미한다. 이러한 상호 간 에 부정적 행동은 Patterson 등(1989)에 근거할 때 점차 악화되 어 이후 보다 심각한 문제행동으로 이어질 수 있기에 이러한 악순환을 막기 위해 부모교육의 필요성이 강조된다. 특히 걸 음마기는 아동의 자기주장이 강해지고 자율성이 발달하면서 본격적으로 부모의 훈육이 시작되는 시기이므로, 걸음마기 자 녀를 둔 부모를 대상으로 이 시기 발달적 특성과 바람직한 양 육행동 등에 대해 다루는 부모교육이 더욱 활성화되어야 한 다.

본 연구의 제한점과 후속 연구를 위한 제언은 다음과 같다. 첫째, 본 연구와 같이 어머니의 양육행동이나 아동의 순응 및 외현화 문제행동에 대해 살펴본 국외의 연구들은 실험실 관찰 을 통해 연구변인들을 측정하고자 시도한데 반해(e.g., Chen et al., 2002; Kochanska \& Kim, 2013; Spinrad et al., 2012), 본 연구 는 모든 연구변인들을 어머니 보고로 측정하였다. 이러한 방 법은 자연스러운 일상생활 속에서 나타나는 어머니와 아동의 행동을 반영할 수 있다는 측면에서 의미가 있으나, 어머니의 개인적 성향에 따라 주관적으로 평가되었을 가능성이 있다. 후속 연구에서는 다양한 보고자를 통해 연구변인들을 측정하 거나 실험실 또는 일상생활 관찰 등을 병행함으로써 보다 객 관적인 자료수집을 통해 세 변인 간 관계를 재확인해볼 필요 가 있다. 둘째, 본 연구는 걸음마기 아동의 순응을 측정하기 위 해 어머니가 부여하는 규칙에 대해 아동이 순응을 얼마나 자 주 나타내는지에 초점을 두어 양적 차원에서 접근하였다. 하 지만 아동이 순응 행동을 보일 때 양육자의 의견이나 지시를 자신의 것으로 전적으로 받아들여 양육자의 감독 없이 순응할 수도 있지만, 때로는 양육자의 통제가 있을 때에만 협력적으 로 행동할 수도 있을 것이다. 이에 국외의 연구들(e.g., Chen et al., 2003; Kochanska \& Aksan, 1995)은 순응의 유형을 보다 세 부적으로 자발적 순응 (committed compliance)과 상황적 순응 (situational compliance)으로 구분하기도 하는데, 추후 연구에 서는 아동이 순응 행동을 보일 때 기분이나 마음, 동기 등을 고 려하여 질적 차원에서 순응 행동을 이해해볼 필요가 있으며, 이러한 순응의 세부적 유형이 어머니의 양육행동과 외현화 문 제행동 간의 관계에서 서로 다른 역할을 하는지에 대해 파악 해보는 것도 흥미로울 것이다. 셋째, 본 연구는 어머니의 양육
행동이 걸음마기 아동의 순응 및 외현화 문제행동에 미치는 영향에 초점을 두고 있으나, 몇몇 선행 연구들에서는 자녀가 보이는 불순응 또는 외현화 문제행동에 대한 반응으로 어머니 의 양육행동이 다르게 나타날 수도 있음을 보고하므로(Smith et al., 2004; Verhoeven et al., 2010), 후속 연구에서는 교류적 관 점에서 어머니의 양육행동과 걸음마기 아동의 순응 및 외현화 문제행동 간의 관계를 양방향적으로 고려해볼 필요도 있다. 마지막으로, 본 연구에서는 어머니의 양육행동을 측정하기 위 해 걸음마기라는 자녀의 발달단계에 적합한 국외의 척도를 번 안하여 사용하였으나, 온정과 구조화의 신뢰도가 상당히 낮은 편으로 나타나 어머니의 긍정적 양육행동의 영향력과 관련된 본 연구결과를 해석하는 데 다소 주의가 요구된다. 일반적으 로 측정하는 문항수가 증가되면 신뢰도가 높아지는 경향이 있 는데(E. H. Lee, Lee, \& Park, 2006), 본 연구에서 사용한 어머니 의 양육행동 척도의 경우 하위요인들이 각 4 문항씩으로 구성 되어 비교적 많지 않은 문항수로 측정되었다. 6 가지 하위요인 들은 Zimmer-Gembeck 등(2015)의 연구에서는 .60 .71의 신 뢰도를, 본 연구에서는 .52 .73의 신뢰도를 보이고 있다. 한 편, 본 연구에서 각 하위요인들을 합쳐 긍정적 및 부정적 양육 행동으로 구분할 경우 .80 과 .86으로 상대적으로 양호한 신뢰 도를 나타내었다. 이에 더해, Zimmer-Gembeck 등(2015)의 연 구에 비해 본 연구의 신뢰도가 낮은 것은 부모가 양육행동을 이해하는 데 문화적 차이가 발생할 수도 있기 때문인 것으로 사료된다.

이러한 제한점에도 불구하고, 본 연구는 걸음마기 아동의 외현화 문제행동의 발달에 대해 이해하고자 그 선행 요인으로 서 개인 외적 변인인 어머니의 양육행동과 개인 내적 변인인 걸음마기 아동의 순응을 함께 살펴봄으로써, 두 가지 변인이 모두 걸음마기 아동의 외현화 문제행동의 발달에 중요함을 확 인하였다. 이를 통해 아동 초기의 외현화 문제행동의 발달적 기원에 대해 이해하는 데 도움이 되었을 것으로 기대한다. 또 한, 본 연구는 어머니의 양육행동이 걸음마기 아동의 외현화 문제행동에 미치는 영향을 다룬 선행 연구들을 보다 확장하 여, 걸음마기 시기에 발달적으로 중요한 개념 중 하나인 아동 의 순응이 양자 간의 관계를 설명하는 기제가 됨을 발견하였 다는 점에서 의의가 있다. 본 연구의 결과는 걸음마기 자녀를 둔 어머니들을 위한 부모교육 프로그램을 개발하거나 아동 초 기의 문제행동 예방을 위한 중재 프로그램을 개발하는 데 기 초자료로 활용될 수 있을 것이다. 


\section{Acknowledgements}

This work was supported by the Ministry of Education of the Republic of Korea and the National Research Foundation of Korea (NRF-2016S1A3A2924375).

\section{Notes}

This article was presented at the 2018 Annual Fall Conference of the Korean Association of Child Studies.

\section{Conflict of Interest}

No potential conflict of interest relevant to this article was reported.

\section{Ethics Statement}

All procedures of this research were reviewed by IRB (164-32).

\section{References}

\section{In English}

Bater, L. R., \& Jordan, S. S. (2017). Child routines and selfregulation serially mediate parenting practices and externalizing problems in preschool children. Child \& Youth Care Forum, 46(2), 243-259. doi:10.1007/s10566016-9377-7

Bornstein, M. H., Hahn, C.-S., \& Haynes, O. M. (2010). Social competence, externalizing, and internalizing behavioral adjustment from early childhood through early adolescence: Developmental cascades. Development and Psychopathology, 22(4), 717-735. doi:10.1017/S0954579410000416

Briggs-Gowan, M. J., \& Carter, A. S. (1998). Preliminary acceptability and psychometrics of the infant-toddler social and emotional assessment (ITSEA): A new adult-report questionnaire. Infant Mental Health Journal, 19(4), 422-445. doi:10.1002/(SICI) 1097-0355(199824)19:4<422::AIDIMHJ5>3.0.CO;2-U

Brook, J. S., Zheng, L., Whiteman, M., \& Brook, D. W. (2001). Aggression in toddlers: Associations with parenting and marital relations. The Journal of Genetic Psychology, 162(2), 228-241. doi:10.1080/00221320109597963

Browne, M. W., \& Cudeck, R. (1993). Alternative ways of assessing model fit. In K. A. Bollen \& J. S. Long (Eds.), Testing structural equation models (pp. 136-162). Newbury Park, CA: Sage.

Byrd-Craven, J., Auer, B. J., Granger, D. A., \& Massey, A. R. (2012). The father-daughter dance: The relationship between father-daughter relationship quality and daughters' stress response. Journal of Family Psychology, 26(1), 87-94. doi: $10.1037 / \mathrm{a} 0026588$

Calkins, S. D., Smith, C. L., Gill, K. L., \& Johnson, M. C. (1998). Maternal interactive style across contexts: Relations to emotional, behavioral and physiological regulation during toddlerhood. Social Development, 7(3), 350-369. doi:10.1111/1467-9507.00072

Chen, X., Chen, H., Wang, L., \& Liu, M. (2002). Noncompliance and child-rearing attitudes as predictors of aggressive behaviour: A longitudinal study in Chinese children. International Journal of Behavioral Development, 26(3), 225-233. doi:10.1080/01650250143000012

Chen, X., Rubin, K. H., Liu, M., Chen, H., Wang, L., Li, D., . . Li, B. (2003). Compliance in Chinese and Canadian toddlers: A crosscultural study. International Journal of Behavioral Development, 27(5), 428-436. doi:10.1080/01650250344000046

Combs-Ronto, L. A., Olson, S. L., Lunkenheimer, E. S., \& Sameroff, A. J. (2009). Interactions between maternal parenting and children's early disruptive behavior: Bidirectional associations across the transition from preschool to school entry. Journal of Abnormal Child Psychology, 37(8), 1151-1163. doi:10.1007/s10802-009-9332-2

Del Vecchio, T., \& O'Leary, S. G. (2006). Antecedents of toddler aggression: Dysfunctional parenting in mother-toddler dyads. Journal of Clinical Child \& Adolescent Psychology, 35(2), 194-202. doi:10.1207/s15374424jccp3502_3

Eisenberg, N., Gershoff, E. T., Fabes, R. A., Shepard, S. A., Cumberland, A. J., Losoya, S. H., . . Murphy, B. C. (2001). Mothers' emotional expressivity and children's behavior problems and social competence: Mediation through children's regulation. Developmental Psychology, 37(4), 475490. doi:10.1037//0012-1649.37.4.475

Eisenberg, N., Taylor, Z. E., Widaman, K. F., \& Spinrad, T. L. (2015). Externalizing symptoms, effortful control, and intrusive parenting: A test of bidirectional longitudinal relations during early childhood. Development and Psychopathology, 27, 953968. doi:10.1017/S0954579415000620

Feldman, R., \& Klein, P. S. (2003). Toddlers' self-regulated compliance to mothers, caregivers, and fathers: Implications for theories of socialization. Developmental Psychology, 39(4), 680-692. doi:10.1037/0012-1649.39.4.680 
Feng, X., Hooper, E. G., \& Jia, R. (2017). From compliance to self-regulation: Development during early childhood. Social Development, 26(4), 981-995. doi:10.1111/sode.12245

Heller, T. L., Baker, B. L., Henker, B., \& Hinshaw, S. P. (1996). Externalizing behavior and cognitive functioning from preschool to first grade: Stability and predictors. Journal of Clinical Child Psychology, 25(4), 376-387. doi:10.1207/ s15374424jccp2504_3

Kalb, L. M., \& Loeber, R. (2003). Child disobedience and noncompliance: A review. Pediatrics, 111(3), 641-652. doi:10.1542/peds.111.3.641

Karreman, A., van Tuijl, C., van Aken, M. A. G., \& Deković, M. (2006). Parenting and self-regulation in preschoolers: A meta-analysis. Infant and Child Development, 15(6), 561579. doi: $10.1002 /$ icd. 478

Keane, S. P., \& Calkins, S. D. (2004). Predicting kindergarten peer social status from toddler and preschool problem behavior. Journal of Abnormal Child Psychology, 32(4), 409-423. doi:10.1023/B:JACP.0000030294.11443.41

Keenan, K., Shaw, D., Delliquadri, E., Giovannelli, J., \& Walsh, B. (1998). Evidence for the continuity of early problem behaviors: Application of a developmental model. Journal of Abnormal Child Psychology, 26(6), 441-452. doi:10.1023/ a: 1022647717926

Kennision, S. M., \& Byrd-Craven, J. (2015). Gender differences in beliefs about infant-directed speech: The role of family dynamics. Child Development Research, 2015, 1-6. doi:10.1155/2015/871759

Kline, R. B. (2015). Principles and practice of structural equation modeling (4th ed.). New York: The Guilford Press.

Kochanska, G. (1991). Socialization and temperament in the development of guilt and conscience. Child Development, 62(6), 1379-1392. doi:10.2307/1130813

Kochanska, G., \& Aksan, N. (1995). Mother-child mutually positive affect, the quality of child compliance to requests and prohibitions, and maternal control as correlates of early internalization. Child Development, 66(1), 236-254. doi: $10.2307 / 1131203$

Kochanska, G., Coy, K. C., \& Murray, K. T. (2001). The development of self-regulation in the first four years of life. Child Development, 72(4), 1091-1111. doi:10.1111/14678624.00336

Kochanska, G., \& Kim, S. (2013). Difficult temperament moderates links between maternal responsiveness and children's compliance and behavior problems in lowincome families. Journal of Child Psychology and Psychiatry, 54(3), 323-332. doi:10.1111/jcpp.12002

Kok, R., van IJzendoorn, M. H., Linting, M., BakermansKranenburg, M. J., Tharner, A., Luijk, M. P. C. M., . . . Tiemeier, H. (2013). Attachment insecurity predicts child active resistance to parental requests in a compliance task. Child: Care, Health and Development, 39(2), 277-287. doi:10.1111/j.1365-2214.2012.01374.x

Kopp, C. B. (1982). Antecedents of self-regulation: A developmental perspective. Developmental Psychology, 18(2), 199-214. doi:10.1037/0012-1649.18.2.199

Kuczynski, L., \& Kochanska, G. (1990). Development of children's noncompliance strategies from toddlerhood to age 5. Developmental Psychology, 26(3), 398-408. doi:10.1037/0012-1649.26.3.398

Laurin, J. C., \& Joussemet, M. (2017). Parental autonomysupportive practices and toddlers' rule internalization: A prospective observational study. Motivation and Emotion, 41(5), 562-575. doi:10.1007/s11031-017-9627-5

Lehman, E. B., Steier, A. J., Guidash, K. M., \& Wanna, S. Y. (2002). Predictors of compliance in toddlers: Child temperament, maternal personality, and emotional availability. Early Child Development and Care, 172(3), 301-310. doi:10.1080/ 03004430212124

Mendez, M., Durtschi, J., Neppl, T. K., \& Stith, S. (2016). Corporal punishment and externalizing behaviors in toddlers: The moderating role of positive and harsh parenting. Journal of Family Psychology, 30(8), 887-895. doi: $10.1037 /$ fam0000187

O’Leary, S. G., Slep, A. M. S., \& Reid, M. J. (1999). A longitudinal study of mothers' overreactive discipline and toddlers' externalizing behavior. Journal of Abnormal Child Psychology, 27(5), 331-341. doi:10.1023/a:1021919716586

Patterson, G. R., DeBaryshe, B. D., \& Ramsey, E. (1989). A developmental perspective on antisocial behavior. American Psychologist, 44(2), 329-335. doi:10.1037/0003066x.44.2.329

Pettit, G. S., \& Bates, J. E. (1989). Family interaction patterns and children's behavior problems from infancy to 4 years. Developmental Psychology, 25(3), 413-420. doi:10.1037/ 0012-1649.25.3.413

Prodromidis, M., Lamb, M. E., Sternberg, K. J., Hwang, C. P., \& Broberg, A. G. (1995). Aggression and noncompliance among Swedish children in centrebased care, family day care, and home care. International Journal of Behavioral Development, 18(1), 43-62. doi:10.1177/016502549501800103

Shaw, D. S., Winslow, E. B., Owens, E. B., Vondra, J. I., Cohn, J. F., \& Bell, R. Q. (1998). The development of early externalizing problems among children from low-income families: A transformational perspective. Journal of Abnormal Child Psychology, 26(2), 95-107. doi:10.1023/ a: 1022665704584

Skinner, E., Johnson, S., \& Snyder, T. (2005). Six dimensions of parenting: A motivational model. Parenting: Science and 
Practice, 5(2), 175-235. doi:10.1207/s15327922par0502_3

Smetana, J. G., Kochanska, G., \& Chuang, S. (2000). Mothers' conceptions of everyday rules for young toddlers: A longitudinal investigation. Merrill-Palmer Quarterly, 46(3), 391-416.

Smith, C. L., Calkins, S. D., Keane, S. P., Anastopoulos, A. D., $\&$ Shelton, T. L. (2004). Predicting stability and change in toddler behavior problems: Contributions of maternal behavior and child gender. Developmental Psychology, 40(1), 29-42. doi:10.1037/0012-1649.40.1.29

Spinrad, T. L., Eisenberg, N., Silva, K. M., Eggum, N. D., Reiser, M., Edwards, A., . . Gaertner, B. M. (2012). Longitudinal relations among maternal behaviors, effortful control and young children's committed compliance. Developmental Psychology, 48(2), 552-566. doi:10.1037/a0025898

van Aken, C., Junger, M., Verhoeven, M., van Aken, M. A. G., \& Deković, M. (2007). The interactive effects of temperament and maternal parenting on toddlers' externalizing behaviours. Infant and Child Development, 16(5), 553-572. doi:10.1002/icd.529

Verhoeven, M., Junger, M., van Aken, C., Deković, M., \& van Aken, M. A. G. (2010). Parenting and children's externalizing behavior: Bidirectionality during toddlerhood. Journal of Applied Developmental Psychology, 31(1), 93-105. doi:10.1016/j.appdev.2009.09.002

Wang, L., Chen, X., Chen, H., Cui, L., \& Li, M. (2006). Affect and maternal parenting as predictors of adaptive and maladaptive behaviors in Chinese children. International Journal of Behavioral Development, 30(2), 158-166. doi:10.1177/0165025406063631

Wood, J. J., Cowan, P. A., \& Baker, B. L. (2002). Behavior problems and peer rejection in preschool boys and girls. The Journal of Genetic Psychology, 163(1), 72-88. doi:10.1080/ 00221320209597969

Zimmer-Gembeck, M. J., Webb, H. J., Thomas, R., \& Klag, S. (2015). A new measure of toddler parenting practices and associations with attachment and mothers' sensitivity, competence, and enjoyment of parenting. Early Child Development and Care, 185(9), 1422-1436. doi:10.1080/03004430.2014.1001753

\section{In Korean}

Baek, J., \& Cho, B. (2010). A study on infant compliance according to the types of care and multiple attachments. Korean Journal of Child Studies, 31(1), 147-162.

Hong, S. (2000). The criteria for selecting appropriate fit indices in structural equation modeling and their rationales. Korean Journal of Clinical Psychology, 19(1), 161-177.

Kim, M. J., \& Yi, S. H. (2004). Maternal parenting values, beliefs about appropriate parenting practice, mothers' control and children's compliance. Journal of Korean Council for Children's Rights, 8(2), 301-325.

Lee, E. H., Lee, M. R., \& Park, S. Y. (2006). Adong yeongubangbeobui ihae [아동 연구방법의 이해]. Seoul: Hakjisa.

Lee, J.-S. (2016). Effects that rules set by mothers to their children, children's compliance, and temperament have on problem behaviors of children (Master's thesis). Retrieved from http:// www.riss.kr/link?id=T14041509

Na, Y.-K., Yee, Y.-H., \& Han, J.-H. (2006). The relationship between infant's temperament and socio-emotional ability. Korea Journal of Child Care and Education, 44, 19-36.

Park, B. (2013). Relations among toddlers' temperament, maternal parenting, and social withdrawal and aggression. Journal of Korean Home Management Association, 31(6), 67-81. doi:10.7466/jkhma.2013.31.6.67

Park, H. S., \& Han, Y. M. (2001). A study on the preschooler's compliance at home and day care setting. Journal of Korean Council for Children's Rights, 5(2), 113-127.

Park, S.-Y. (2006). Child development. Paju, KR: Gyomoon publishers.

Park, S.-Y., Rubin, K. H., Chung, O. B., Yoon, C. H., \& Doh, H.S. (2007). Toddler's compliance as a function of gender, temperament, and inhibition of the child, and maternal child-rearing attitudes. Korean Journal of Child Studies, 28(4), 1-17.

Park, S.-Y., \& Shin, Y.-A. (2007). Variables related to toddler's compliance: Child's gender, age, temperament, mother's parenting and the content of demands. Journal of the Korean Home Economics Association, 45(6), 11-20.

Pu, S.-S. (2010). The relationships among mothers' conceptions of everyday rules, children's compliance, and temperament. Korean Journal of Early Childhood Education, 30(5), 219-239. doi:10.18023/kjece.2010.30.5.010

Shin, N., Doh, H.-S., Kim, M.-J., Song, S.-M., Kim, S. J., Yun, K. B., \& Doo, J. I. (2014). The mediating effects of maternal control strategies on the relationship between preschoolers' temperament and compliance/noncompliance. Korean Journal of Child Studies, 35(6), 135-152. doi:10.5723/ kjcs.2014.35.6.135

Shin, N., Park, B., Kim, S., \& Doh, H.-S. (2015). Reciprocal relations between maternal parenting behavior and preschoolers' compliance/noncompliance during motherchild interactions: A short-term longitudinal study. Korean Journal of Child Studies, 36(5), 75-94. doi:10.5723/ kjcs.2015.36.5.75

Song, H. (2018). The longitudinal influence of maternal depression and anxiety on noncompliance and externalizing behavior problems of preschool children: The mediation effect of harsh maternal parenting behavior. Korean Journal of Child Studies, 39(1), 119-128. doi:10.5723/kjcs.2018.39.1.119 
Song, H., \& Choi, K.-S. (2007). The influence of maternal control strategy types on children's compliance/noncompliance behaviors during a cleanup situation. Korean Journal of Early Childhood Education, 27(6), 255-272. doi:10.18023/ kjece.2007.27.6.012

Song, J. J. (2015). Nonmunjakseonge piryohan SPSS/AMOS tonggyebunseokbangbeop [논문작성에 필요한 SPSS/AMOS 통계분석방법]. Paju, KR: 21Cbook.

Sung, H. W., \& Han, S. Y. (2015). Effects of mother's affectionate parenting, psychological behavioral control on young children's problem behaviors: Mediating effect of selfcontrol. Korean Journal of Childcare and Education, 11(4), 271-292. doi:10.14698/jkcce.2015.11.271

Um, S. A., \& Park, S.-Y. (2006). Toddler's aggressive behavior. Journal of the Korean Home Economics Association, 44(6), 59-69.

Yong, E.-S., \& Park, S.-Y. (2011). Preschoolers' compliance and noncompliance: As a function of maternal behavior, child gender and age and social context. Korean Journal of Child

Studies, 32(3), 43-57. doi:10.5723/kjcs.2011.32.3.43

\section{ORCID}

Bokyung Park

Minjoo Kim

Nana Shin

Kibong Yun

Jee Un Noh http://orcid.org/0000-0002-8194-1675

http://orcid.org/0000-0003-2969-079X

http://orcid.org/0000-0002-7869-6875

http://orcid.org/0000-0001-5065-4297

http://orcid.org/0000-0002-9254-5336
Received January 16, 2019

Revision received February 8, 2019

Accepted February 18, 2019 